\title{
As senhoras e as donas nas vilas de Bragança e de Ourém (Pará, Brasil) no século XIX
}

\section{Ladies and mistresses at Bragança and Ourém villages (Pará state, Brazil) in the 19th century}

Denilma Santos Figueiredo ${ }^{1}$

Resumo: A realidade amazônica é um tema diverso, que abrange um vasto conjunto de atores. Nessa contribuição, analisaremos, através de testamentos e inventários post-mortem das Vilas de Bragança e Ourém do século XIX, o papel de um grupo de mulheres na sociedade rural daquele contexto, na posse e manutenção do patrimônio familiar herdado, colaborando assim para a superação do estereótipo de mulher branca frágil e submissa, através do qual aquelas senhoras são não raro representadas.

Palavras-chaves: Patrimônio rural, mulheres proprietárias rurais, herança.
Abstract: The Amazon reality is a diverse topic that concerns to a wide range of actors. In the present contribution, we analyze, through testaments and post-mortem inventories from Bragança and Ourém Villages in the XIX century, the role performed by a group of women in the rural society of that time, as possessors and maintainers of the familiar heritage, helping to get over the fragile and submitted white woman stereotype, through which those ladies are not rarely represented.

Keywords: Rural property, rural landowners women, heritage.

\footnotetext{
${ }^{1}$ Mestre em Agriculturas Familiares e Desenvolvimento Sustentável, Programa de PósGraduação em Agriculturas Amazônicas, Universidade Federal do Pará/Empresa Brasileira de Pesquisa Agropecuária - Amazônia Oriental. A pesquisa contou com a concessão de bolsa de mestrado à autora, através da Coordenação de Aperfeiçoamento de Pessoal de Nível Superior - CAPES, entre os anos de 2010 e 2012. E-mail: denilmahist@bol.com.br
} 


\section{INTRODUÇÃO}

Bragança e Ourém foram Vilas de antiga colonização pela Coroa Portuguesa, que adotou políticas de atração populacional para consolidar o Grão Pará. A análise da efervescência social e econômica da região (em especial durante o século XIX), entretanto, tem reservado pouco espaço para a mulher como sujeito ativo da história.

Por um tempo, a historiografia limitou a análise do trabalho feminino no Brasil Colônia ao trabalho das escravas e alforriadas, sugerindo que estivesse atrelado às negras, e reservando, às mulheres brancas, o estereótipo de reprodutoras ${ }^{2}$. Para $\mathrm{Silva}^{3}$, "estamos perante um colonialismo às avessas, em que a negra e a parda são colocadas sob os holofotes da pesquisa histórica, enquanto a branca é remetida para o mundo oculto da casa ou do convento e ali esquecida".

Nesse contexto, buscaremos conhecer alguns aspectos da vida de mulheres com posses nas Vilas de Bragança e Ourém no século XIX. Para tanto, analisaremos seu patrimônio, através de testamentos e inventários post-mortem. A análise da composição do patrimônio permite a interpretação do padrão de vida das mulheres, apontando a existência de utensílios, de porções de terra, de plantações e de produção rural (agrícola, de pastos e extrativista), de joias e de escravos ${ }^{4,5}$. Conhecer o patrimônio permite que a discussão sobre a história dessas mulheres ultrapasse a análise do núcleo doméstico, chegando à vida pública. Assim, as mulheres afirmam sua existência e passam a ser vistas como agentes históricos ativos.

\section{MÉTODO}

Os testamentos e inventários post-mortem, disponíveis no acervo do Arquivo Público do Estado do Pará, foram selecionados de acordo com a existência de marcas de status ou condição social das inventariadas (pessoas

2 OLIVEIRA, Laizeline Aragão de. Dona Joaquina do Pompéu: contribuições para o abastecimento da América portuguesa (1764-1824). Revista Brasileira de História \& Ciências Sociais, São Leopoldo - RS, v. 1, n. 2, p. 1-13, dez. 2009.

3 SILVA, Maria Beatriz Nizza da. Donas e Plebeias na sociedade colonial. Lisboa: Estampa, 2002. p. 79

${ }^{4}$ SAMARA, Eni de Mesquita. A família na sociedade paulista do século XIX (1800-1860). São Paulo, 1980. 357 p. Tese (doutorado). Faculdade de Filosofia, Letras e Ciências Humanas, Universidade de São Paulo.

5 ARAÚJO, Maria Lucilia Viveiros. Os caminhos da riqueza dos paulistanos na primeira metade dos oitocentos. São Paulo, 2003. 270 p. Tese (doutorado). Faculdade de Filosofia, Letras e Ciências Humanas, Universidade de São Paulo. 
- no caso, mulheres - de cujo patrimônio se fazia o inventário, indicando seu espólio) ou inventariantes (as beneficiárias na divisão do espólio das inventariadas). Consideraram-se aquelas que possuíam as nomenclaturas de Dona ou Senhora, assim como aquelas declaradas como viúvas, tutoras e/ou filhas de homens ligados à guarda nacional, filhas de proprietários de engenhos, de proprietários de escravos, de proprietários de sortes de terras, de imóveis urbanos, de gados vacuns, assim como aquelas em cujo rol dos inventários e testamentos constavam peças de valor significativo à época.

Durante a verificação dos testamentos e inventários post-mortem, foi possível constatar a interação entre o conteúdo e o teor dos documentos analisados, com o próprio processo de partilha do patrimônio e as tentativas de contestação das escolhas testamentárias naquele contexto colonial. Por fim, pudemos classificar aquelas proprietárias como mulheres com grande fortuna, medianas ou pobres. Para se chegar a essa constatação sobre as categorias existentes com base na valoração dos espólios, foram observados os ativos que apresentavam os maiores valores em cada período do XIX (conforme datação do testamento ou inventário): a princípio, o ativo escravo; em seguida, os imóveis rurais e urbanos; por fim, as dívidas ativas.

\section{OS INVENTÁRIOS DAS VILAS DE BRAGANÇA E OURÉM}

A constituição dos testamentos e inventários post mortem variou entre as mulheres pesquisadas, de acordo com sua classificação como inventariantes ou inventariadas (Figura 1) e conforme a Vila onde moravam.

Figura 1 - Quantidade relativa de mulheres inventariantes e inventariadas identificadas na documentação pesquisada.

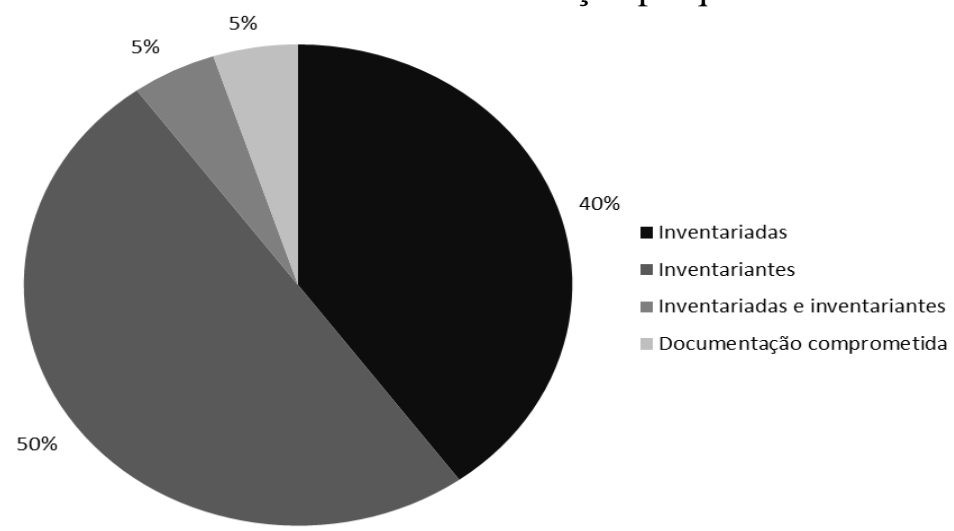

Todos os casos em que a mulher representada era simultaneamente inventariante e inventariada no mesmo processo foram originados na Vila 
de Bragança. Em relação aos documentos comprometidos, cabe informar que sofreram danos advindos da ação de traças, tendo sido possível, deles, extrair apenas algumas informações incompletas. Levando-se em consideração as categorias de inventariantes e inventariadas e o lugar de registro do processo de inventário, as mulheres referenciadas nas fontes foram classificadas, a priori, em quatro grupos, apresentados a seguir.

As inventariadas da Vila de Bragança (Figura 2) foram mulheres em cujos processos frequentemente constavam animais de produção, imóveis rurais (ambos citados com maior frequência percentual em relação aos demais conjuntos de documentos), a peça escrava e joias. Com menor frequência, restrita à metade dos casos, aparecia citada a produção agrícola/extrativista/pecuária.

Figura 2 - Frequência dos tipos de bens arrolados nos inventários das inventariadas da Vila de Bragança.

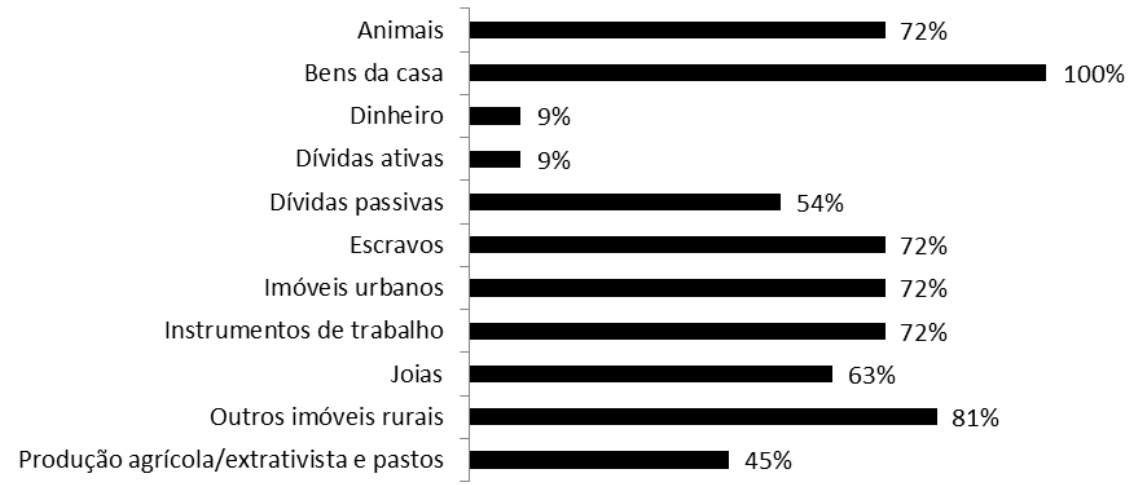

As inventariantes da Vila de Bragança (Figura 3) eram menos abastadas, apresentando menor frequência relativa de inventários citando a peça escrava, a produção agrícola/extrativista/pecuária, os animais de produção, os imóveis urbanos, os instrumentos de trabalho e os bens de casa, além de não ter sido citada posse de joias.

Nota-se que, embora vivessem ambas na Vila de Bragança, inventariadas e inventariantes vivenciavam uma existência econômica divergente, em que as primeiras detinham, por seu patrimônio, condições mais favoráveis de reprodução social. O único elemento que contradiz esta visão é o fato de que o conjunto de documentos das inventariantes da Vila de Bragança foi o único, dentre os quatro totais, em que a frequência de dívidas ativas (a receber) foi maior que a de dívidas passivas (a pagar). 
Figura 3 - Frequência dos tipos de bens arrolados nos inventários das inventariantes da Vila de Bragança.

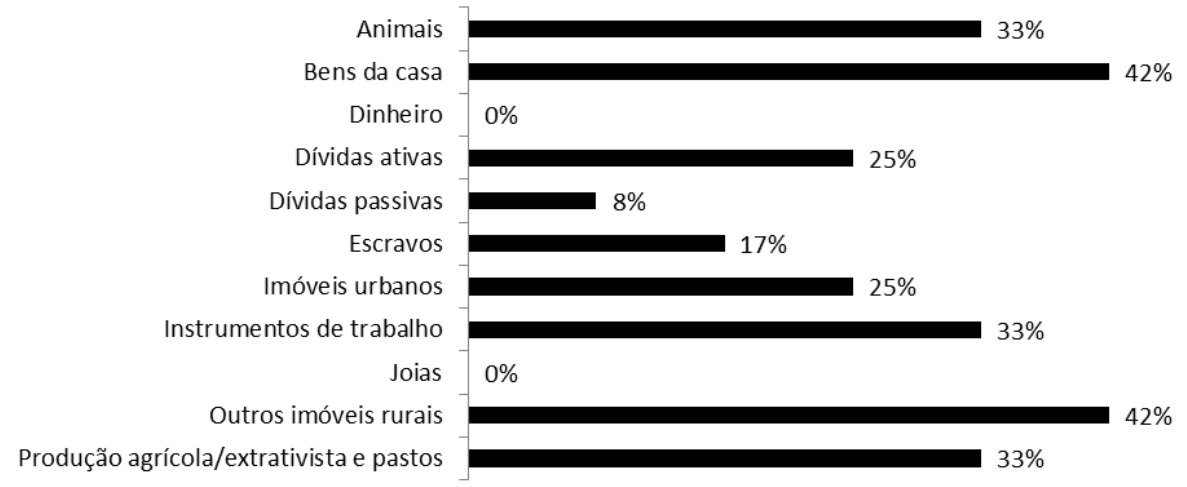

As dívidas ativas representam uma forma segura de riqueza ${ }^{6}$. Nas duas Vilas investigadas, de modo geral, as dívidas ativas serviram como herança durante a partilha do legado, dado o valor significativo que apresentavam, o que denota, nesse contexto, uma suposta prosperidade ou acúmulo de bens. Foram marcantes as dívidas ativas em que pessoas influentes estavam em condição de devedoras de aluguéis de casas na cidade, o que ilustrava os investimentos também na área urbana.

Especificamente em relação às proprietárias da Vila de Bragança, eram mulheres envolvidas em atividades agropecuárias, havendo algumas com mais de 100 animais vacum e cavalar. Ou seja, apesar da baixa frequência de inventários citando determinado ativo, esta condição não determinaria baixa concentração do ativo citado.

As inventariadas da Vila de Ourém (Figura 4), mas também as inventariantes (Figura 5), figuraram como aquelas cujos inventários possuíam, todos, menção à peça escrava. Os inventários das mulheres da Vila de Ourém apresentaram maior homogeneidade, com frequência menor de citações a animais de produção e joias. As inventariadas de Ourém, especificamente, possuíam, todas, referência à produção agrícola/ extrativista/pecuária, mas nenhuma referência a dinheiro, enquanto o conjunto de documentos das inventariantes tinha uma baixa frequência de

\footnotetext{
6 ALMICO, Rita de Cássia da Silva. Fortunas em movimento: um estudo sobre a transformação de riqueza pessoal em Juiz de Fora/1870-1914. Campinas, 2001. 164 p. Dissertação (mestrado). Instituto de Economia, Universidade Estadual de Campinas. 
referências à produção e a maior acerca de dinheiro, dentre os quatro grupos considerados.

Figura 4 - Frequência dos tipos de bens arrolados nos inventários das inventariadas da Vila de Ourém.

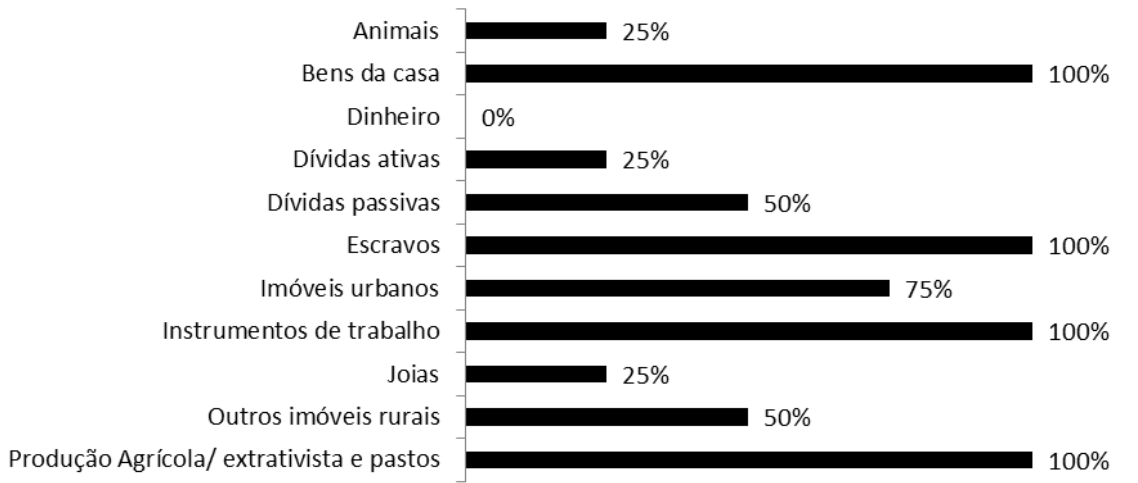

Figura 5 - Frequência dos tipos de bens arrolados nos inventários das inventariantes da Vila de Ourém.

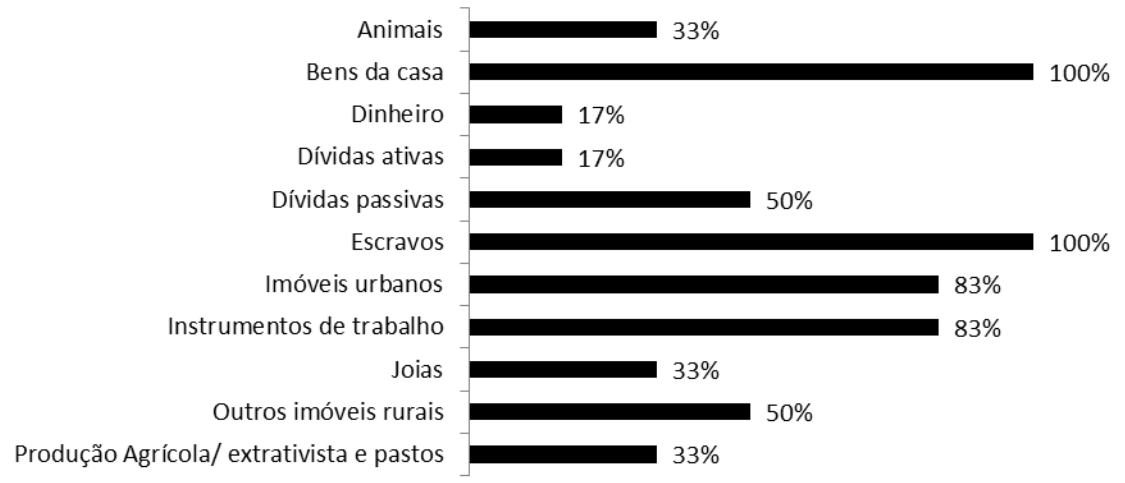

\section{BENS DE SUPORTE ÀS ATIVIDADES PRODUTIVAS}

Dentre os bens de suporte à produção, destacaram-se os animais, os instrumentos de trabalho e os imóveis. Embora os escravos fossem predominantemente vistos como mercadorias, e embora tivessem importante papel nas atividades produtivas geradoras de renda, serão mencionados apenas mais adiante, devido suas peculiaridades. 
Os animais apareceram, nos inventários, como semoventes. Foram encontrados no rol dos itens inventariados: gado vacum, gado cavalar, vacas solteiras, vacas, bezerros, novilhos, burros, jumentos, cabras, ovelhas, carneiros. Animais como galinhas e patos não foram mencionados, mas isso não significa que não existiam, podendo transparecer que essas aves não possuíam valor elevado.

Quanto aos instrumentos de trabalho, o que mais se verificou foi a presença de rodas de ralar, supostamente usadas para a mandioca, bem como descaroçadores de algodão. Esses itens se destacaram, pois a área de estudo apresentava, naquele contexto, produção significativa de algodão e mandioca. Aquelas mulheres tinham posses de uma grande variedade de gêneros agrícolas, destacando-se: algodão, arroz, milho, cana-de-açúcar, mandioca, café e laranja.

De acordo com os itens arrolados nos inventários, podemos afirmar que as inventariantes e inventariadas, além de serem proprietárias rurais, também possuíam outras atividades, estando direta ou indiretamente envolvidas com a tecelagem, em virtude do número significativo de instrumentos de trabalho como: rodas de fiar algodão, teares, ferro de engomar, etc. Esses dados indicam que havia produção de tecidos, redes e outros panos, o que configuraria uma estratégia produtiva diversificada.

Os imóveis, por sua vez, foram referenciados, na documentação, como bens de raiz, que são, de acordo com Martinez (2006, p. 144), simultaneamente, terras de culturas, campos e pastos para criar animais, terrenos urbanos, casas, sobrados, enfim, toda estrutura imobiliária da sociedade.

\section{O ATIVO ESCRAVO}

Um importante item detectado nos inventários e testamentos foi o ativo escravo. Na Figura 6, podemos observar a quantidade de escravos e sua classificação nos gêneros masculino e feminino, de acordo com a localidade de origem e a condição da mulher envolvida no processo.

Embora os processos de inventários da Vila de Ourém indiquem uma quantidade superior de escravos em relação à quantidade encontrada na Vila de Bragança (173 da primeira, contra 80 da segunda), a peça escrava ocorreu em uma quantidade maior de processos na Vila de Bragança. Como resultado dessa disparidade, a quantidade relativa de escravos (número absoluto dividido pelo número de processos considerados) na Vila de 
Bragança também foi menor que o encontrado na Vila de Ourém (4 escravos por inventário em média nesta Vila, frente a 14 escravos por inventário em média naquela).

Figura 6 - Sexo do ativo escravo (n. de inventários entre parênteses).

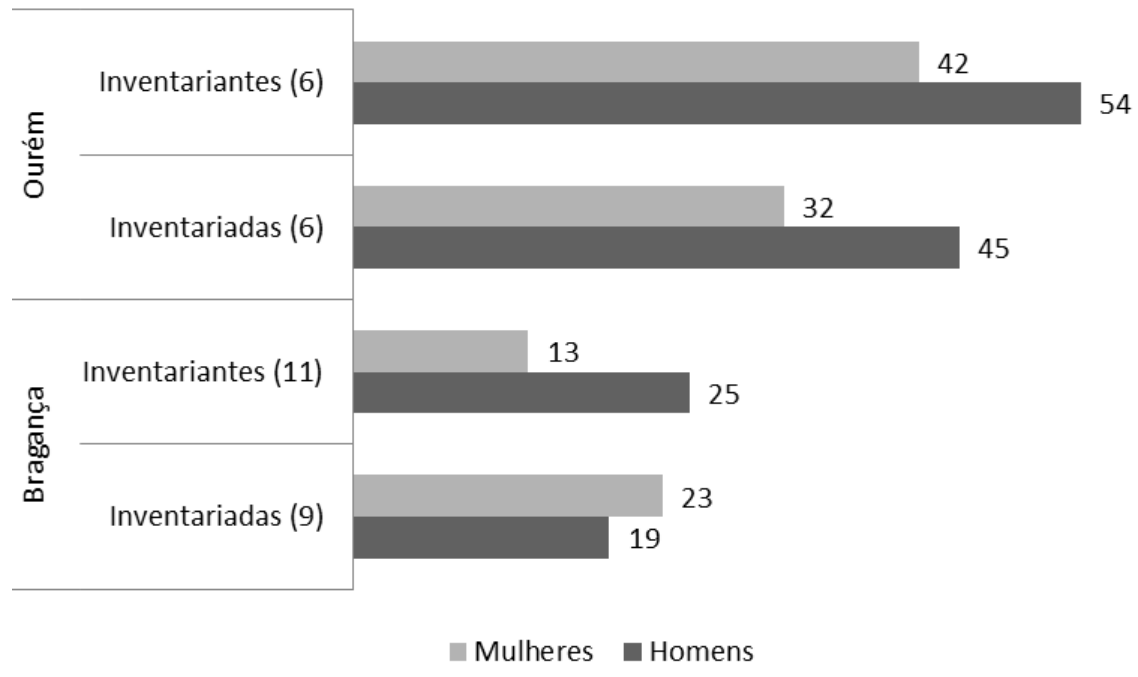

A presença feminina nas escravarias representava, considerando-se tanto inventariantes quanto inventariadas, em média, $45 \%$ na Vila de Bragança e $42 \%$ na Vila de Ourém, de modo que não houve grande diferença entre as referidas Vilas na constituição das escravarias quanto ao gênero da peça escrava. Em ambos os casos, entretanto, a presença masculina na composição das escravarias apresentou discreta vantagem (a despeito da existência de mais escravas que escravos referenciados nos processos das inventariadas da Vila de Bragança).

Para Carvalho ${ }^{7}$, números equilibrados entre homens e mulheres nas escravarias apontam indícios de reprodução em cativeiro. Tal situação foi verificada nos autos dos inventários, pois encontramos, na descrição dos escravos, referências do tipo "filho de tal escravo", "mulher de fulano de tal", denotando a formação de famílias entre os cativos.

7 CARVAlHO, Enaile Flauzina. Política e economia mercantil nas terras do Espírito Santo (1721-1821). Vitória, 2008. 159 p. Dissertação (mestrado). Centro de Ciências Humanas e Naturais, Universidade Federal do Espírito Santo. 
Outro dado levantado se referiu à idade dos escravos (Figura 7). A maior concentração de escravos na faixa etária de 15 a 59 anos se deve ao vigor físico que as pessoas têm nesta etapa da vida, possibilitando maior produtividade no trabalho e preferência por parte dos senhores de escravos. Em relação aos mais idosos, foram encontrados poucos registros de sua presença, o que se deve à baixa longevidade (ligada à degradante condição de vida à qual eram submetidos) e ao desinteresse dos senhores em manter escravos doentes e improdutivos.

Notou-se, também, apreciável quantidade de cativos com até sete anos de idade, caracterizando a procriação entre os escravos, que geralmente mantinham seus filhos por determinado tempo, depois do que não mais poderiam deliberar sobre seu futuro, cabendo-o ao dono. Conforme Pastana ${ }^{8}$, os escravos eram geralmente comercializados desde os três anos de idade, até os 50.

Figura 7 - Idade (em anos) do ativo escravo nos inventários.

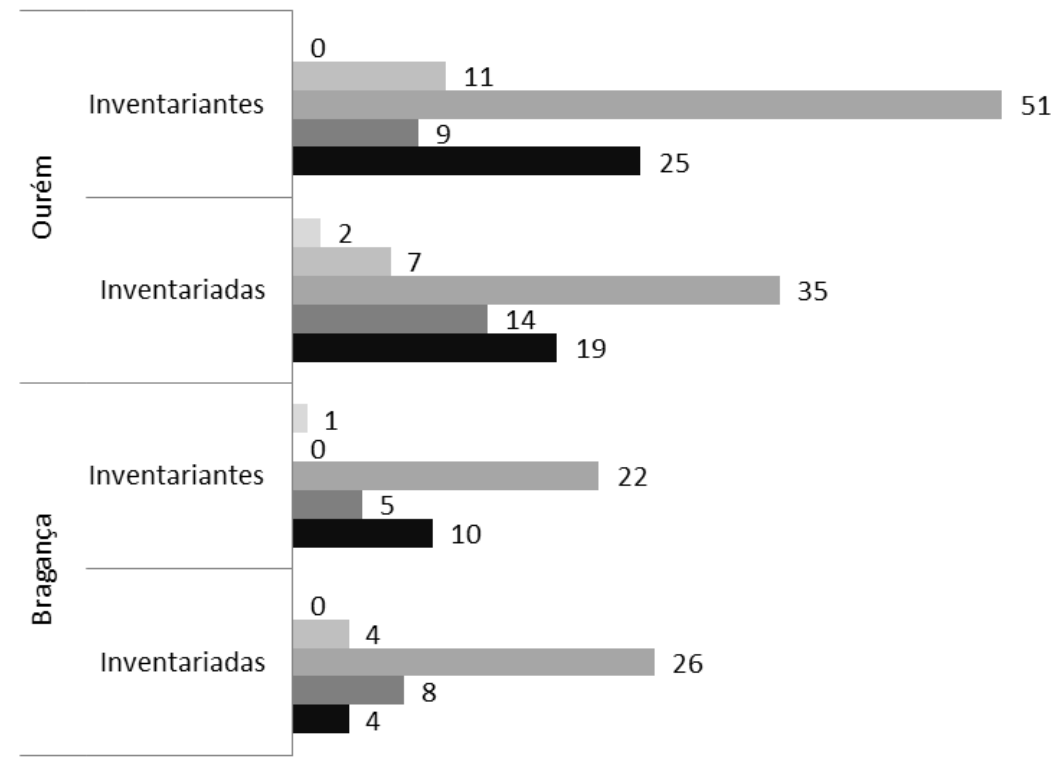

Sem informação $\square 0$ ou mais Entre 15 e 59 Entre 8 e 14 até 7

\footnotetext{
${ }^{8}$ PASTANA, Andréa da Silva. Em nome de Deus, amém!: mulheres, escravos, famílias e heranças através dos testamentos em Belém do Grão Pará na primeira metade do século XIX. Belém, 2008. 158 p. Dissertação (mestrado). Faculdade de História, Universidade Federal do Pará. p. 83
} 


\section{A PEÇA ESCRAVA COMO SÍMBOLO DE RIQUEZA}

O escravo constituía uma propriedade de grande valor, tanto pela sua condição de mercadoria (apta à compra e à venda), quanto por seu potencial de prestação de serviço ${ }^{9}$. Assim, a presença do escravo no rol dos documentos, como herança durante a partilha, mostrou ser um elemento importante na manutenção do patrimônio de determinadas famílias.

Durante a primeira metade do século XIX, o escravo era tido como símbolo de riqueza ${ }^{10}$, entretanto, as fugas, as doenças e a velhice foram indícios que constatamos interferir de maneira negativa no patrimônio das famílias pesquisadas, já que caracterizavam um risco ao patrimônio ${ }^{11}$. $\mathrm{O}$ testamento e o inventário de Dona Senhorinha (década de 1850) ilustram o valor significativo do escravo, pois um cativo podia valer mais que uma sorte de terras, ou a metade do valor, em virtude da idade e da condição física. Entre 1855 a 1862, entretanto, houve o declínio da peça escrava, e outros ativos assumiram o lugar do cativo de maneira expressiva, como os aluguéis de imóveis urbanos e as dívidas ativas.

A peça escrava, à luz da legislação que regeu o processo de abolição, foi assunto de inúmeras discussões acerca da reconfiguração ou da decadência dos patrimônios. A reconfiguração se deu pela substituição do cativo por outros investimentos, enquanto a decadência se caracterizou como empobrecimento ${ }^{12}$, pelo declínio de famílias para camadas sociais inferiores, em virtude da dissolução patrimonial.

\section{OBJETOS DE OSTENTAÇÃO}

Outros itens expressivos foram os trastes, objetos pequenos que, diferente do significado atual, tinham algum valor. A partir de sua análise, podemos caracterizar os costumes e dar ideia de conforto e riqueza ${ }^{13}$. Dentre

\footnotetext{
${ }^{9}$ Ibidem, p. 78

${ }^{10}$ Ibidem, p. 83

${ }^{11}$ ALMEIDA, Joseph Cesar Ferreira de. Entre engenhos e canaviais: Senhoras do açúcar em Itu. São Paulo, 2008. 120 p. Dissertação (mestrado). Faculdade de Filosofia, Letras e Ciências Humanas, Universidade de São Paulo.

12 MARTINEZ, Claudia Eliane Parreiras. Cinzas do passado: riqueza e cultura material no vale do Paraopeba/MG (1840/1914). São Paulo, 2006. 313 p. Tese (doutorado). Faculdade de Filosofia, Letras e Ciências Humanas, Universidade de São Paulo.

${ }^{13}$ SAMPAIO, Patrícia Maria Melo. Os fios de Ariadne: tipologia de fortunas e hierarquias sociais em Manaus, 1840-1880. Manaus: Editora da Universidade do Amazonas, 1997.
} 
os objetos arrolados, identificamos um número significativo de trastes de ouro, prata e cobre, além de peças que, segundo Mota ${ }^{14}$, eram sinônimo de beleza, sofisticação e ostentação:

Hum Relógio de prata fino; Hum cordão de ouro; Does par de brinco de fino; Huma Bengala de cana da India com seo castão e argolla de Prata valor 1\$600. (Inventariante D. Supriana Roza. Vila de Ourém. 1817).

Outros itens de destaque, e que podemos classificar como objetos de ostentação, eram os objetos religiosos, como hábitos de Cristo, assim como adereços, bengalas, chapeos, vestimentas de ordem militar, entre outros, pertencentes a homens e mulheres distintos, da elite social da época.

\section{A TRANSMISSÃO DO PATRIMÔNIO NAS VILAS DE BRAGANÇA E DE OURÉM}

\section{ORDENAÇÕES FILIPINAS}

A legislação do testamento foi regida, até 1916, pelas Ordenações Filipinas $^{15}$, que, dentre outras matérias, admitiam que os testamentos e os inventários post-mortem fossem os documentos utilizados para legalizar o processo de transmissão de bens entre a pessoa falecida e seus herdeiros, na sociedade colonial. Informavam os procedimentos a serem tomados após a morte do indivíduo ${ }^{16}$.

Para o testamento ter validade, deveria atender a alguns requisitos. Exigia-se que fosse escrito e assinado pelo testador ou outras pessoas de seu rogo. Devia ser feito em presença de cinco testemunhas, lido diante delas e, depois de lido, assinado por elas, sendo o próximo passo levá-lo até o tabelião, que reconheceria as testemunhas e o testador, dando validade às suas últimas vontades ${ }^{17}$.

\footnotetext{
${ }^{14}$ MOTA, Antonia da Silva. Cotidiano e cultura material nos séculos XVIII-XIX. Ciências Humanas em Revista, São Luís, v. 5, p. 189-200, jun. 2007.

15

ORDENAÇÕES FILIPINAS. Lisboa: Fundação Calouste Gulbenkian, 1985 (facsimile da edição comentada de Cândido Mendes CÓDIGO PHILIPHINO. Rio de Janeiro: Typografia do Instituto Philomático, 1870. Livro III e IV, Título LXXXI. Impresso).

${ }^{16}$ STANCZYK FILHO, Milton. À luz do cabedal: acumular e transmitir bens nos sertões de Curitiba (1696-1805). Curitiba, 2005. 133 p. Dissertação (mestrado). Setor de Ciências Humanas, Letras e Artes, Universidade Federal do Paraná. p. 38

${ }^{17}$ Ibidem, p. 34
} 
Se alguém morresse abintestado (sem deixar testamento), os herdeiros legítimos (filhos e esposa) deveriam assumir o legado; na sua falta, assumiriam os ascendentes. Havendo testamento, porém, a lei garantia que "morto o marido, a mulher fica em posse e cabeça do casal"18, tornando-se meeira do marido, e somente a ela caberia alienar ou não o patrimônio. Ser meeira significava ter direito à metade dos bens do casal, pois os casamentos eram realizados por carta de ametade ${ }^{19}$. A outra metade dos bens seria destinada aos filhos de matrimônio e aos reconhecidos. Se não houvesse descendentes, os ascendentes poderiam assumir a outra metade da herança, sendo considerados os parentes de até décimo grau. Não havendo ascendentes, a mulher seria herdeira universal, assumindo as duas metades da herança.

Entretanto, a mesma lei que amparava as viúvas, enquanto meeiras, limitava o seu poder enquanto tutoras de seus filhos, pois eram consideradas incapazes de gerir seus bens, sendo necessária a orientação de um homem, com intuito de assegurar contra a dilapidação do patrimônio. As disposições Filipinas ainda determinavam que, caso a mulher viúva, de posse de seus filhos, contraísse novas núpcias, perderia sua tutela. Essa determinação assegurava o patrimônio contra a ação de aproveitadores.

A tutoria feminina era permitida pelas Ordenações Filipinas, se acompanhada de um fiador que se responsabilizasse pelo patrimônio da família. Essa situação condiz com o pensamento da época, de que a mulher seria incapaz de gerir seu patrimônio ${ }^{20}$. Conforme o Livro IV, Título 107: “a nós pertence prover, que ninguém use do mal que tem, querendo suprir a fraqueza do entender das mulheres viúvas, que depois da morte de seus maridos desbaratam tudo que tem".

Em relação às filhas, a legislação estabelecia que estariam excluídas do rol de herdeiros, caso contraíssem casamento sem permissão dos pais, e caberia ao Estado julgar o perdão. Na ausência de filhos homens, a filha seria herdeira, se comprovasse ter realizado um bom casamento ${ }^{21}$. Isso evidencia que as Ordenações Filipinas interferiam diretamente na vida privada da sociedade colonial.

\footnotetext{
${ }^{18}$ PASTANA, op. cit., p. 31

${ }^{19}$ Ibidem, p. 28

${ }^{20}$ MELO, Hildete de Pereira; MARQUES, Teresa Cristina Novaes. A partilha da riqueza na ordem patriarcal. Revista de Economia Contemporânea, Rio de Janeiro, v. 5, n. 2, p. 155 179, 2001.

${ }^{21}$ Ibidem, p. 163.
} 


\section{A MULHER CAPAZ}

Para Leite ${ }^{22}$, "as mulheres dos fazendeiros frequentemente, quando ficam viúvas, administram sozinhas as fazendas e os escravos, assumindo integralmente as responsabilidades". Os documentos das Vilas de Bragança e de Ourém confirmam essa situação, em que viúvas gerenciavam as unidades rurais na ausência dos maridos.

Ademais, foram identificados, nas referidas Vilas, casos em que o testador fez, de sua mulher, herdeira universal, sem necessidade de fiador; concordamos, portanto, com Falci ${ }^{23,24}$, para quem as leis de partilha e posse do patrimônio, em alguns casos, não eram seguidas de forma rigorosa. Algumas mulheres, inclusive, obtiveram a tutela dos filhos, quando houve previsão testamentária e confirmação do Juiz Órfãos.

Todavia, antes de assumir a gerência dos bens herdados, era necessário que as proprietárias contabilizassem as dívidas passivas contraídas pelo inventariado e testador, geralmente seu marido, que deveriam ser pagas antes da divisão da herança ${ }^{25}$. Embora Silva ${ }^{26}$, analisando documentos da junta de comércio do início do XIX, tenha encontrado casos de fragmentação do patrimônio familiar em virtude de dívidas, na área de estudo, esta fragmentação não foi significativa.

Não podemos, porém, inferir que a gerência feminina da unidade rural no Brasil Colônia tenha decorrido apenas da morte dos maridos. Outras causas foram o evento cabano (que se estendeu às Vilas, especialmente Ourém), as dificuldades econômicas e a migração masculina para a abertura de novas áreas de lavoura ${ }^{27}$.

\footnotetext{
${ }^{22}$ LEITE, Miriam Moreira. A condição feminina no Rio de Janeiro, século XIX: antologia de textos de viajantes estrangeiros. São Paulo: HUCITEC; Brasília: INL/Fundação Nacional Pró-Memória, 1984. p. 57

${ }^{23}$ FALCI, Miridan Britto Knox. Um estudo para a história social: os inventários de 1796 a 1820 no Rio de Janeiro. Revista do instituto histórico e geográfico do Rio de Janeiro, Rio de Janeiro, n. 2-3, p. 143-162, 1989.

${ }^{24}$ FALCI, Miridan Britto Knox. Mulheres do sertão nordestino. In: PRIORE, Mary Del. (org.). História das mulheres do Brasil. 3. Ed. São Paulo: Contexto, 2006. p. 241-278

${ }^{25}$ MELO; MARQUES, op. cit.

${ }^{26}$ SILVA, Maria Beatriz Nizza da. Herança no Brasil colonial: os bens vinculados. Revista de ciências históricas, Porto, v. 5, p. 291-319, 1990.

${ }^{27}$ SAMARA, Eni de Mesquita. As Mulheres, o poder e a família: São Paulo, século XIX. São Paulo: Marco Zero/Secretaria de Estado da Cultura de São Paulo, 1989.
} 


\section{A REVELAÇÃO DO TEOR DO TESTAMENTO: DO MATERIAL AO ESPIRITUAL}

Para Radcliffe-Brown ${ }^{28}$, herança é a transferência de status, baseada na relação entre dois membros de um grupo social: aquele que transmite e o que recebe. É no momento da leitura do testamento que ocorre a partilha do patrimônio dos bens do testador entre os membros da família, sendo repleto de expectativas, arrependimentos e contestações, traduzindo os privilégios e compensações das relações no âmbito familiar.

Nessa dinâmica, se destaca a figura do testamenteiro, o responsável pela execução das últimas vontades, pela organização dos ritos funerários, das missas, das esmolas, que guarda, em sua pessoa, laços de confiança em relação ao testador:

Eram personagens centrais no sistema de garantias acionados pelo testador, pois a ele cabia a responsabilidade de, com correção e lisura, levar a termo as disposições testamentárias, e assim a escolha exigia bastante ponderação do testador para ter a certeza de que seus bens seriam passados para quem lhe conviesse $\mathrm{e}^{29}$.

A presença de pessoas influentes e de respeito, como religiosos, a exemplo do Vigário, na Vila de Ourém, dotava de veracidade as escolhas do testador. Pessoas como capitães ou sargentos também foram encontradas com certa frequência, ora como testamenteiros, ora como testemunhas.

Durante a identificação dos testamentos, foi possível verificar as aflições, compensações, privilégios, não apenas de integrantes das famílias, mas também de agregados, como escravos e também afilhados. A peça escrava pôde se enquadrar como algo relevante no que tange à compensação, pois se verificou um número significativo de escravos alforriados pela morte de seu Senhor.

Embora Araújo ${ }^{30}$ tenha documentado uma mudança de mentalidade nas práticas testamentárias dos oitocentos, destacando que a questão

\footnotetext{
${ }^{28}$ RADCLIFFE-BROWN, Alfred Reginald. Estrutura e função nas sociedades primitivas. Lisboa: Edições 70, 1989.

${ }^{29}$ STANCZYK FILHO, op. cit., p. 52

30 ARAÚJO, Maria Lucilia Viveiros. As práticas testamentárias paulistanas na primeira metade do século XIX. Revista História Hoje, Manaus, v. 3, n. 9, p. 1-24, abr. 2006. p. 5
} 
espiritual vinha perdendo espaço, em detrimento de questões de teor material, pudemos identificar as questões de cunho espiritual nas Vilas de Bragança e Ourém. O imaginário religioso nas Vilas pesquisadas não perdeu seu espaço, pois, ali, verificaram-se pedidos referentes ao funeral, enterro, rezas, pedidos de perdão e reconhecimento de erros:

Declara que se mande rezar uma capela de missas para os seus paiz, para as almas do purgatório, pelas almas dos fallecidos forem ou pella intenção dos que vivo reacharem de todos os indios que tenho ocupado nomeo cerviso e que por algum medo lhe seja responsável a qualquer restituição respectivo a seos sallarios, para as almas ou intenções das pessoas com quem teve contas e negocios. (Testamento de Maria Ignácia. Vila de Ourém. 1826).

Segundo Freyre ${ }^{31}$ e Pastana ${ }^{32}$, a binômia entre valores espirituais e materiais fazia com que a morte do senhor despertasse tanto expectativas de liberdade, quanto tensões, entre os escravos. Para Pastana ${ }^{33}$, um motivo de contendas era que alguns senhores, devido à prestação de serviços e aos laços de convívio ou para amenizar suas "culpas", libertavam escravos e deixavam, como herança para o alforriado, outro escravo, que poderia, inclusive, ser membro da família do alforriado:

Deixa forro o seu escravo Zacarias filho da Cafuza Valentina e o rapaz Caetano deixa para escravo de Zacarias, e por morte daquele, escravo Caetano ficará para sua mulher.

O fato de um escravo receber outro escravo como herança já tinha sido relatado:

Constatou-se a (...) escravidão entre os cativos, parecendo ser contraditória a mudança de escravo a 'senhor de escravo'. O sistema de escravidão permitiu a presença de escravos utilizando o trabalho e serviços de outros escravos para seu sustento. A posse de um escravo pela população forra ocorria através das heranças e da compra ${ }^{34}$.

Mas a alforria, antes de ser ato estritamente advindo do arrependimento senhorial, era um reflexo das estratégias dos cativos, que,

\footnotetext{
${ }^{31}$ FREYRE, Gilberto. Casa grande \& senzala. 34. Ed. Rio de Janeiro: Record, 1998.

${ }^{32}$ Op. cit.

${ }^{33}$ Ibidem, p. 134

${ }^{34}$ Ibidem, p. 122
} 
visando alguma forma de compensação futura, se dedicavam à boa prestação de serviço para com a família do senhor. Outra situação de suposta bondade do senhor para com os cativos, identificada nos autos dos inventários, foi a permissão para o cultivo de roças de subsistência:

Hum citio xeio de rocinhas e cafés dos escravos em duzentos brassos de terras propias da parte de lla do rio ximuqui; indo destz villa para tentugal a mao direita. (Trecho de inventário da Vila de Bragança. 1809).

Para Portela ${ }^{35}$, tal atitude seria uma tentativa de controlar os cativos, pois a roça de subsistência levaria os escravos ao apego a terra, evitando a fuga. Sendo assim, compensaria que o senhor disponibilizasse um pedaço de terra pra esse fim.

Quando, porém, não foram alforriados, $40 \%$ dos escravos referenciados na documentação analisada foram repassados às filhas, às viúvas e irmãs dos testadores. Essa constatação coaduna com Araújo ${ }^{36}$, para quem as mulheres passariam a ser privilegiadas e/ou amparadas pelos testadores. Verificou-se também que uma grande parcela das proprietárias rurais deu atenção aos seus netos, deixando-os amparados durante a partilha de bens, sendo também a peça escrava item da herança.

\section{CONTESTAÇÃO DOS TESTAMENTOS}

Os testamentos e inventários post-mortem das referidas Vilas revelaram conflitos geridos por petições de anulação de testamentos e novas avaliações dos bens nos inventários, durante o processo de partilha. Isso ocorria porque o testamento era um sustentáculo das predileções, vontades e arrependimentos do testador, dos quais nascia a insatisfação de determinados membros da família ${ }^{37}$.

Alguns casos de insatisfação estavam relacionados à prática do testamento Nuncupativo, que seria uma enunciação oral do testador, a qual necessitaria ser confirmada por testemunhas para adquirir legitimidade ${ }^{38}$. Era um recurso utilizado por pessoas que adoeciam subitamente, morrendo

\footnotetext{
${ }^{35}$ PORTELA, Bruna Marina. Caminhos do cativeiro: a configuração de uma comunidade escrava (Castro, São Paulo 1800-1830). Curitiba, 2007. 108 p. Dissertação (mestrado). Setor de Ciências Humanas, Letras e Artes, Universidade Federal do Paraná.

${ }^{36}$ Op. cit.

${ }^{37}$ SILVA, op. cit., p. 62.

${ }^{38}$ STANCZYK FILHO, op. cit.
} 
distante da Vila, ou que adiavam a feitura do testamento perante o escrivão e, de repente, morriam.

Sobre as contestações encontradas, temos a de Jose Henrique Lopes, Tenente, irmão do falecido, que discordou da divisão dos bens, em que a mulher do testador ficou como herdeira de sua meição, através de testamento Nuncupativo (também objeto de protesto). A figura religiosa do Vigário, envolvido no processo como testemunha, entretanto, transpareceu veracidade ao ato da partilha. A respeito destas querelas:

(...) a situação do testamento, e posterior inventário, apresenta sempre um potencial de tensão e conflito: os herdeiros defendem seus interesses, e frequentemente se desentendem, (...); os agregados e dependentes em geral vivem a incerteza da permanência de arranjos passados; e os escravos, via de regra [são] o elo mais frágil ${ }^{39}$.

\section{ESMOLAÇÕES, HERANÇA DE NEGROS E DE DÍVIDAS ATIVAS E PASSIVAS}

As doações e esmolações fizeram parte do contexto das referidas Vilas, a citar as disposições testamentárias de José Antonio Pinheiro, que:

Declara a doação de esmolas: a Confraria do Santissimo Sacramento daquela freguesia 10\$000; a Confraria de Nossa Senhora do Rozario 10\$000; Para o aseio do Altar de São João $10 \$ 000$ e a mesma quantia para Santo Antonio para o mesmo fim.

A gratidão para com os entes queridos também se traduziu nos testamentos:

Declara que deu a sua filha Narciza hum cazal de escravos, que custarão trezentos e trinta mil reis; Deu um escravo ao seu filho Domingos Antonio em remuneração do muito trabalho que ele tem com os negocios de caza.

O cativo surge como importante forma de pagamento. Segundo Pastana $^{40}$, "os inventários e testamentos (...) são fontes valiosas para a compreensão da importância do escravo no mundo do trabalho e na

39 CHALHOUB, Sidney. Visões da liberdade: uma história das últimas décadas da escravidão na corte. São Paulo: Companhia das letras, 2003. p. 20

${ }^{40}$ Op. cit., p. 53 
transmissão de bens de algumas famílias". Logo, podemos inferir que sua participação no rol dos testamentos se estabelecia como peça significativa até o início da década de 1850.

A cobrança das dívidas ativas direcionada a parentes, por sua vez, foi uma situação identificada, no levantamento das fontes, como o acúmulo de bens por dívidas, que supostamente elevou a condição social das mulheres das Vilas de Bragança e de Ourém, a exemplo do inventário de José Antonio Pinheiro, do ano de 1809:

Declara várias pessoas desta vila lhe devem entre elas: o Alferes Antonio Fernandez, deve $800 \$ 000$, que em troca do dinheiro emprestado lhe passou uma escritura pública para requerer "os Ouros vencidos" pelo empréstimo do dinheiro e pela divida em sua loja de fazenda que consta em seu livro de "asentos"; O Alferes Miguel João da Costa deve a quantia de 615\$000; Manoel Joze Francisco morador na Ribeira de Turiasú lhe deve $800 \$ 000$ e os demais devedores constam no dito livro de "asentos".

Os aluguéis em áreas urbanas, caracterizados como dívidas ativas, tornaram-se mais profusos como disposições testamentárias a partir da década de 1860. As leis do processo de abolição seriam as responsáveis por tal alteração, pois obrigavam que se buscassem novos investimentos para suprir a ausência da mão-de-obra escrava. A este fenômeno, Almico ${ }^{41}$ denominou "urbanização da riqueza pessoal", em que os bens rurais perdiam destaque em relação aos investimentos urbanos.

Encontramos também, nas disposições, a declaração do reconhecimento dos débitos, ou seja, dívidas passivas. Segundo Faria ${ }^{42}$ : "o reconhecimento das dívidas tornava-se mais importante do que estabelecer sufrágios da alma. Não mais era do que o reconhecimento dos erros e a tentativa de amenizar suas faltas ao assumi-las".

\section{CLASSIFICANDO A DIMENSÃO DAS FORTUNAS}

Como o presente estudo trata de patrimônio, ou seja, os bens de uma família, podemos, a partir do rol que o compõe, classificar a riqueza ou a pobreza em dada sociedade e dada época. Classificamos, portanto, as proprietárias das Vilas de Bragança e Ourém, como de pequena, mediana ou

\footnotetext{
${ }^{41}$ Op. cit.

42 FARIA, Sheila de Castro. A colônia em movimento. Rio de Janeiro: Nova Fronteira, 1998.
} 
grande fortuna, com base nos ativos constantes nos inventários. Para representar tais categorias, destacamos algumas mulheres de cada Vila, em caráter exemplificativo. Note-se que, apesar da centralidade da peça escrava nessa categorização, também consideramos outros ativos (dívidas ativas, animais, etc.), e os critérios mobilizados, em algumas situações, não foram seguidos na íntegra, havendo casos em que nem mesmo o ativo escravo mostrou ser determinante.

\section{MULHERES COM PEQUENA FORTUNA}

Dentre as proprietárias com pequena fortuna ou menos abastadas, apresentamos, da Vila de Ourém, do ano de 1819, a testadora Roza Maria do Rosário, que deixou, para dois herdeiros: uma escrava com 70 anos de idade, uma sorte de terras com casa e um baú de pau amarelo. Outra proprietária rural da Vila de Ourém, também de pequenas posses, foi Anna Francisca do Espírito Santo, do ano de 1840, cujo inventário continha:

2/4 de caza e um corredor nesta vila de Ourém Cobertas de Telha já muito danificadas na Rua Bragança pegadas de um lado com as cazas de Joze Ignacio Costa e de outro lado de com as Cazas de Luiz Raimundo de Moura a parte esquerda rio Acima.

Um Sítio de sua vivenda denominado Oiteiro com caza de Vivenda Coberta de Palha e a Telheiro que serve de despejo Coberto de Telha.

Em instrumentos de trabalho, constavam apenas "um taxo de cobre e uma roda de fiar algodão". Nos bens de casas, encontramos "três baús de pau amarelos". Não constavam joias. Possuía apenas dois escravos e dois animais de carga. Como herdeiro, tinha seu marido, Manuel Ribeiro da Cunha, seu inventariante.

Em relação à menos abastada da Vila de Bragança, temos o caso de Guiomar Maria de Jesus, que deixou oito herdeiros, sendo seu patrimônio composto por um sítio com casa coberta de palha, com uma pequena roça de mandioca e um forno de fazer farinha; uma escrava com 20 anos de idade; um boi pequeno de carga; um par de rosetas de ouro com duas oitavas de peso; instrumentos de trabalho como canoa pequena, rede de pescar e roda de fiar; dívidas passivas no valor de 81\$640.

\section{MULHERES COM FORTUNAS MEDIANAS}


Testamento e inventário post-mortem de Rita Maria dos Reis, da Vila de Ourém, de 1838, traziam monte-mor de 3:525\$618 réis, tendo, como inventariante, seu filho Ignácio Joaquim Cordeiro, além de outros quatro herdeiros. No testamento, citavam-se 17 escravos (a maioria na faixa etária entre 26 e 36 anos), duas moradas de casas com roças, certa variedade de joias de ouro e utensílios de prata. Também constavam canoas, balanças, descaroçadores de algodão, roda de fiar, agulhas e baús. Havia dívidas ativas de pessoas influentes. Alguns dos herdeiros eram devedores das dividas ativas herdadas, e a própria testadora também devia a um dos herdeiros a quantia de $110 \$ 000$.

Na Vila de Bragança, a inventariada Rosalina Maria da Conceição, que deixou dois filhos menores de 12 anos, tinha posses medianas. Seu legado era composto por: uma casa coberta de palha, três braças de terrenos, um sítio com plantações de mandioca e casa de vivenda coberta de palha com 40 pés de laranjas; foices, machados, enxadas, rodas de ralar mandioca; joias e objetos religiosos; baús e garrafas; não possuía escravos, animais, dinheiro, nem dívidas ativas. Embora em comparação com a proprietária de fortuna mediana da Vila de Ourém, a Dona Rosalina pareça ser de poucas posses, vale lembrar que os inventários da Vila de Bragança indicaram que suas proprietárias viviam uma situação econômica menos abastada, em relação à outra Vila.

\section{MULHERES COM GRANDES FORTUNAS}

Dona Supriana Rosa, uma das mulheres mais abastadas da Vila de Ourém, foi inventariada em 1817. Viúva de um Capitão de milícias reformado, ela assumiu o legado do casal, composto por quatro sortes de terras, com casas e roças de mandioca, milho, algodão, arroz e árvores frutíferas; 19 ranchos; sítios com casa; 49 escravos; animais de carga; alambiques, roda de ralar, rodas de fiar, descaroçadores de algodão e arroz, balanças de ferro, canoas, carroças, tear; vestuário requintado, quase sempre com a denominação e/ou qualificação de fino, como "chapéu fino, cazacão fino, vestido azul fino"; joias abundantes, objetos religiosos; e acessórios, como:

Reloge de Prata com sua caixa de Casco e corrente, xava de Prata com sua Pedra Branca, Fivella de Prata dourada que pezou três oitavas e meia ( $\$ 080$ cada oitava), Xapa de Prata com as Armas douradas de Talabarte, um Par de fivellas de sapatos e outro de ligas todos de Prata, 147 oitavas de Prata, um Par de fivellas de Prata de sapatos. 
Na Vila de Bragança, consideramos o inventário de José Antonio Pinheiro, no ano de 1809, como de fortuna abastada, que teve, como herdeiros, quatro menores e a casada Andreza Maria de Jesus (inventariante). Contava com dívidas a receber de 3:243\$235 réis. O legado era composto por 20 escravos; duas moradas de terras com casa e roças e plantações de algodão, mandioca, cana, arroz e café; 221 animais (gado cavalar e vacum); foices, machados, tachos, canoas, caldeirões; bofetes, baús, cadeiras, mesas, faqueiros de prata, alcovas; vestidos novos; objetos finos:

Muldas (trastes) de Prata, calção e cullete tudo de Setim Preto escuro, vestido novo de pano fino escuro, uma Farda nova de oficial inferior cem Dragonas, de pano fino encarnado, xapeo novo, de pello (cagalloado) gallão de ouro, xapa de Prata Dourada (De Buldriel).

\section{CONSIDERAÇÕES FINAIS}

O patrimônio das proprietárias rurais das Vilas de Bragança e de Ourém no XIX variava sobremaneira. Logo, não havia um padrão estabelecido. Algumas apresentavam, em sua composição patrimonial, itens como escravos em abundância; outras, imóveis na área urbana, assim como na área rural; outras, também possuíam animais, joias, objetos de valor, além de produtos agrícolas. Observamos, portanto, que as mulheres de posses nas referidas Vilas possuíam um papel fundamental na dinâmica econômica e social em suas localidades, contrapondo o discurso de que seriam ociosas e incapazes.

O presente estudo significa um passo não apenas na historiografia de Bragança e de Ourém, mas também na historiografia das mulheres com posses rurais no século XIX, que passam a ser vistas como responsáveis pela formação e manutenção do patrimônio rural. Espera-se que, a partir dessa investigação, novos estudos possam ser propostos e realizados, buscando elucidar o passado da figura feminina na Amazônia, através da documentação disponível e da literatura já acumulada.

Artigo enviado em julho de 2013; aprovado em novembro de 2013. 